\title{
（142）フタル酸処理イカ油の重合と乾燥性
}

（昭 和 30 年 1 月 17 日受理）

丸茂 秀雄・中 島

工業的に得られる魚油の酸価は比較的高いものが多く，イカ油 ではとくにこの傾向が大である。加水分解によって遊離脂肪酸と 付随してモノ，ジグリセリドが生成するが，モノ，ジグリセリト はアルカリ精製によっても除去されず，精製油にあくまで残留す る。イカ油をアルカリ精製し，さらに低温エステル基交換，脱口 ウによって飽和酸基を除去したイカ分別油の乾燥性が不十分なの は今までの研究 (第 1 4 報) ドに原因があることが明らかとなった。イカ分別油に含まれるモ ノ、ジグリセリドの旅離水酸基をマレイン酸, フタル酸でエステ ル化すれば, 乾燥性が完全に硬化乾燥を行うまで改善されること は上記の一つの有力な実証例であろ5。続いて第 5 報5)ではマレ イン酸処理イカ分別油について熱重合と乾燥性，酎候性およびワ ニスとしての実用性の大要を明らかにして，工業的にマレイン酸 処理イカ分別油を利用する場合の諸問題の解決をはかった。モノ， ジグリセリドの遊離水酸基のエステル化をフタル酸で行ってるイ カ分別油の乾燥性は十分に改善されるが3)，Bradley6) は無水フタ ル酸の官能基は 2 であるが，無水マレイン酸では二重結合の分が 加算されて官能基は 3 であるといっている。それでフタル酸を使 った場合には第 5 報のマレイン酸処理油の場合と熱重合ならびに 重合油の乾燥性になんらかの差が生じることが予期される。

そこで, フタル酸処理イカ分別油の熱重合を行って, 重合油の 性状の変化, 重合速度および重合機構, 重合油の乾燥性を検討し たのが本報である。すずフタル酸処理イカ分別油の重合油の性状 の変化を示したのが第 1 表である。重合油の性状は大体マレイン 酸処理油の場合と同様の経過をたどって变化している。しかし重 合速度定数は第 2 表に示すよ 5 に, マレイン酸処理油の值より著 しく低く, 重合の活性化熱も $18.3 \mathrm{kcal} / \mathrm{M}$ (マレイン酸処理油で は $12.8 \mathrm{kcal} / \mathrm{M}$ )でかなり高いが, なおアマニ油の $35.6 \mathrm{kcal} / \mathrm{M}^{7)}$ より潬かに低い。第 5 報のマレイン酸処理油では，マレイン化付 加結合は起っていないか，または起ったとしてもごく僅かである と認められたので，重合速度のマレイン酸処理油とフタル酸処理 油の差はマレイン酸基の二重結合の官能基によるものと思われ た。フタル酸処理油とアマニ油の活性化熱の差は魚油の高度不館 和酸とリノレン酸の差によるものであろ5。第 1 表の性状を不飽 和度の減少度合 $p$ と関連して考察すると，やはり第 5 報と同様に

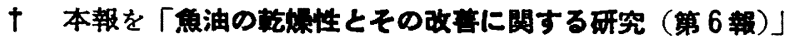
とする.

* ライオン油脂株式会社研究部 : 東京都江戸川区.

1）丸茂, 䈏山, 油脂化協 3，9 (1954).

2）丸茂，富山，油脂化協 3，67 (1954).

3）丸茂，富山，油脂化協 3，70 (1954).

4）丸茂，富山，中島，油脂化協 3，109 (1954).

5）丸茂, 中島, 富山, 工化 58, 424 (1955).

6) Bradley, Ind. Eng. Chem. 29, 440 (1937), 30, 689 (1938).

7) H. E. Adams, P. O. Power, J. Applied Chem. 17, 325 (1946).
重合はこの実験範囲内では主として分子間に行われていると認め られた。重合油の乾燥試験ですマレイン酸処理油と同じ傾向が認 められた。

\section{実䫍の 部}

而合能料 第 5 報とまったく同じ操作で低温エステル基交換， 脱口ウを行い, 酸価 0.5 , ヨウ素価 185.2 , 渱点 $1^{\circ} \mathrm{C}$ のイカ精慗 油から次の性状のイカ分別油を分離した。

曼点 $-10^{\circ} \mathrm{C}$, 酸価 0.9, ヨウ素価 200.1 , ケン化価 178.2 , アセチル価 15.6，分子量（ラスト法）899，総脂肪酸ヨウ素 価 212.0, 同中和価 186.0 , 固体酸 wt \% 8.76, 同ヨウ素価 10.0 .

固体酸は鉛塩アルコール法による。固体酸の不飽和酸をオレイ ン酸とした場合の飽和酸含量計算值は $7.78 \mathrm{wt} \%$ 。

イカ分別油のフタル酸処理は第 3 報にしたがって無水フタル酸 使用量の理論值約 $2.8 \%$ をむとめ, 同じ操作で無水フタル酸 1 , $2,3 \%$ を $250^{\circ} \mathrm{C} て ゙ 2$ 時間作用させて処理油の乾燥試験をしてみ た。1\%では乾燥性は十分に改善されず，2，3\%では同程度に改 善されたので，第 3 報 表-1 No. M-15 にあわせるため $2 \%$ 処理 油（酸価 6.0）を本実験試料として性状を第 1 表 No. B-0 に示 した 2 。試料は念のため $2 \mathrm{mmHg}$ 堿圧で $100^{\circ} \mathrm{C}$ に加熱してこん 跡の無水フタル酸を除いた。この試料は性状からみてすでに一部 に重合が起っている。

重合方法 第 5 報と同じ操作で 230,250, $280^{\circ} \mathrm{C}$ で熱重合を行 った。

重合䊅果 結果を総括して第 1 表に示す。重合油の性状はマレ イン酸処理油の場合と同じ経過で変化するが, 重合油のヨウ素価 の低下度合が若干小さいよ5である。塩化ヨウ素試験結果から高 度不飽和酸基は重合油のヨウ素価 115.7 から 119.4 の間で消失

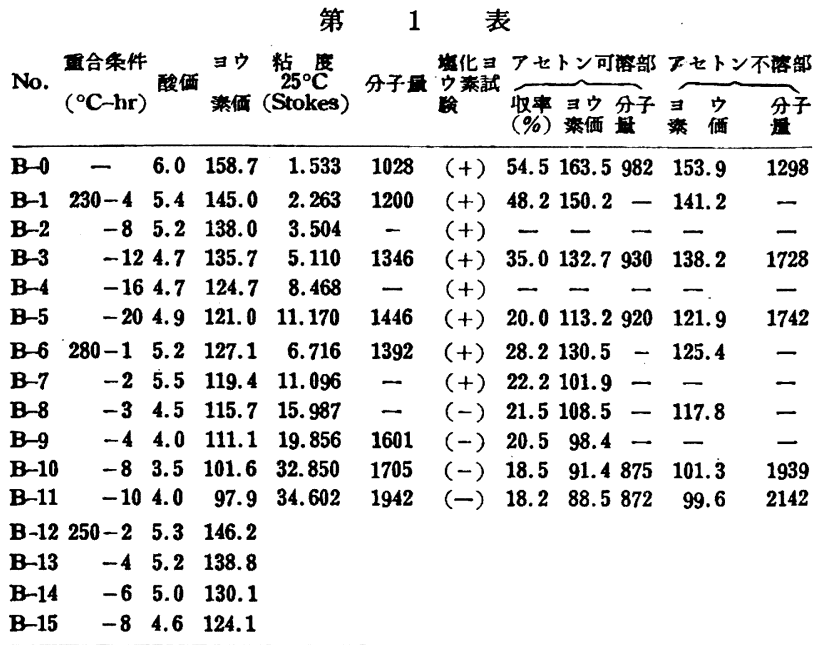

类密には固体酸の不飽和酸はオレイン酸のみでなくて, $\mathrm{C}_{20}$, $\mathrm{C}_{24}$ ठ含まれている。

※2 性状の分析方法はすぺて第 5 報に同じ. 


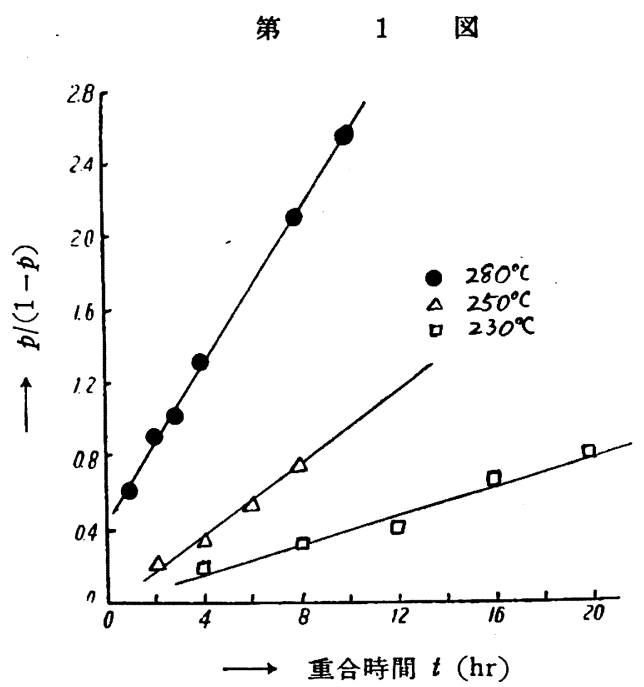

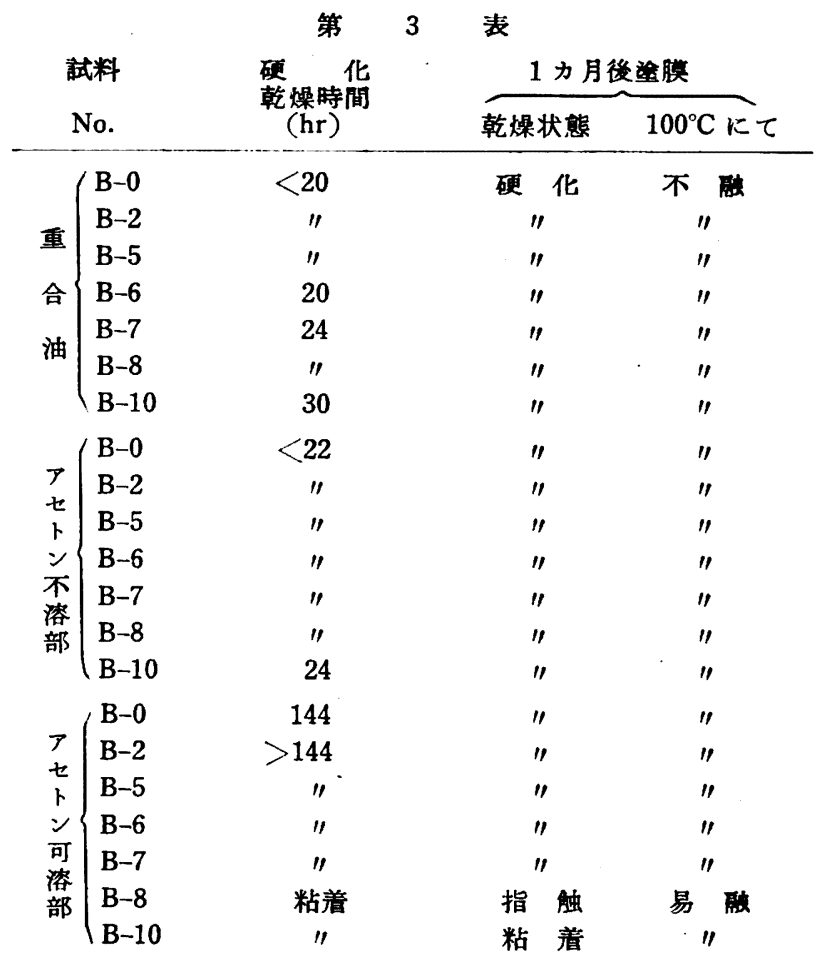

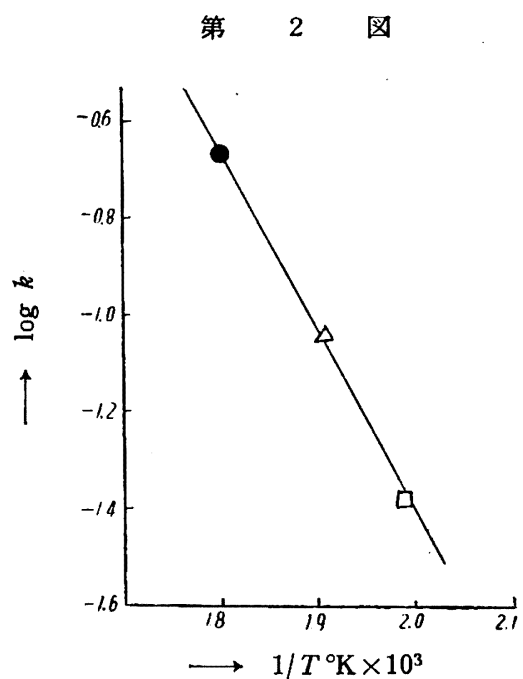

第 3 因

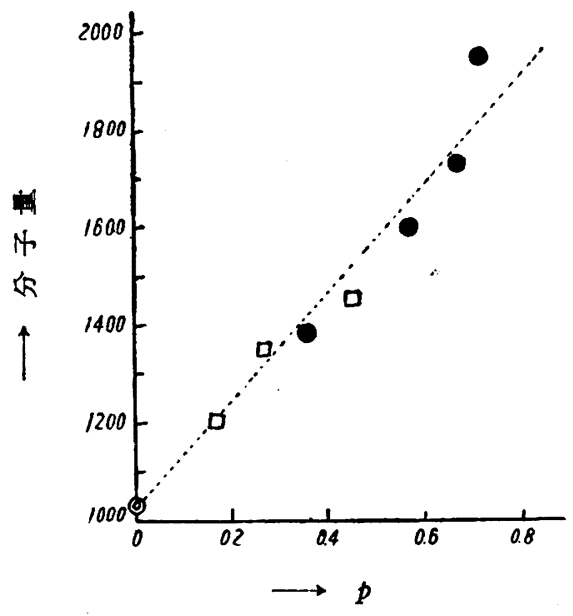

第 1 図のよ5に直線が得られるので $p /(1-p)=k t$ にしたがって 重合速度定数 $k$ は第 2 表のよ 5 に求められた。

\begin{tabular}{cccc} 
& 第 & 2 & 表 \\
重合温度 $\left({ }^{\circ} \mathrm{C}\right)$ & 230 & 250 & 280 \\
\hline 速度定数 $(k)$ & $0.04_{0}$ & $0.08 \mathrm{~s}$ & $0.21_{5}$
\end{tabular}

$\log k$ を重合温度（ $T^{\circ} \mathrm{K}$ ) の逆数に対してプロットすると第 2 因のように值線となる。したがって Arrehnius の式から重合の 活性化熱を求めて $18.3 \mathrm{kcal} / \mathrm{M}$ の値を得た。

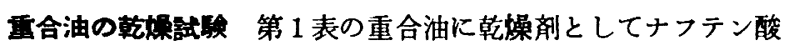
コバルト (Co $8 \%) 0.2 \%$, ナフテン酸マンガン $(\mathrm{Mn} 8 \%) 0.3$ \%を加えて JIS K-5460 にしたがって調合白要鍀ペイント 1 級 $\mathrm{A}$ をつり, $20 \sim 23^{\circ} \mathrm{C}$, 相対湿度 $60 \sim 70 \%$ で乾燥試験を規定の よ5に行った。結果を第 3 表に示す。

重合油の乾燥速度は重合が進むにつれて少しずつ低下している が，36 時間以内に完全に硬化乾燥を行5。アセトン不溶部は 24

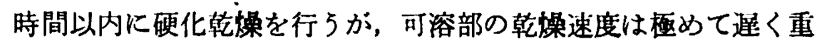

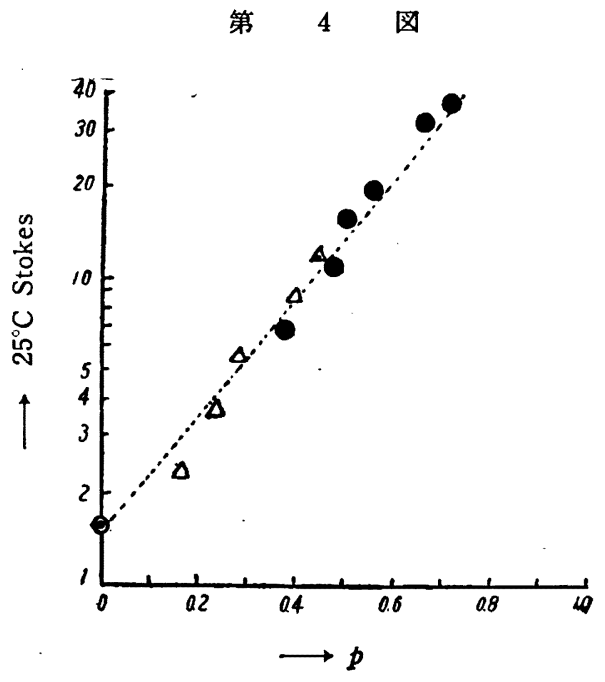




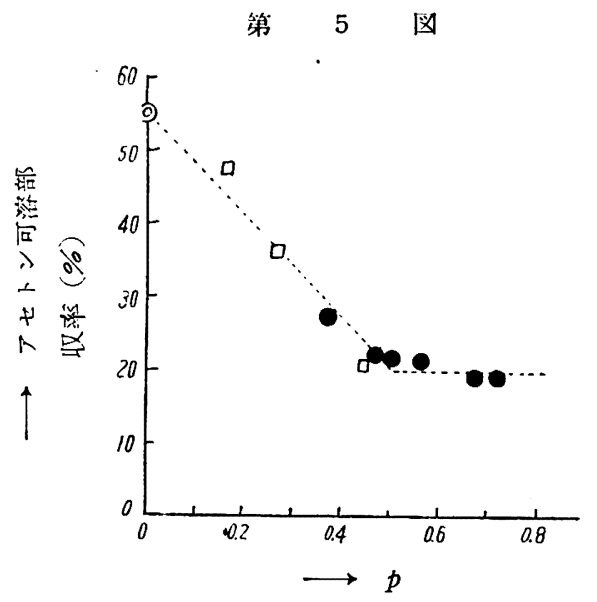

合が進むと遂には硬化乾燥に至らなくなり乾燥性を失う。

この間の事情は第 5 報のマレイン酸処理油の場合とまったく同 様である。塗膜を暗所に 1 カ月おいた場合の黄変は塩化ヨウ素試 験が（十）のものには明らかに認められたが，（一）のものには

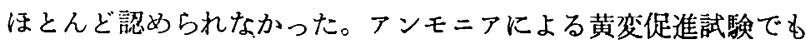
闰様の傾向が示された。

重合機構 第 5 報ではマレイン酸処理イカ分別油の重合は, 実 験範四内では主として分子間に行われていた。本報のフタル酸処 理油でもすでに一部に重合が起っているので，本実験範四内に限 定して重合機棈を考察してみよう。
第 1 表の重合油の分子量, 粘度, アセトン可溶部収率と $p$ との 関係を示すと第 $3 ， 4,5$ 図になる。粘度，分子量は $p$ と直線的 に比例して增しており, アセトン可溶部の収染も $p=0.5$ 付近ま では $p$ と直線的に比例して減少し， $p>0.5$ ではほぼ一定となる。 アセトン可溶部およびこれが一定値をとる理由については，すで に第 5 報でのべたので省略する。以上からフタル酸処理油の重合 はマレイン酸処理油の場合と同様に，主として分子間に行われて いると考えられ，重合温度は重合速度にのみ影響を与え，各温度 に扮ける重合機構は同一であることがわかる。

\section{総括}

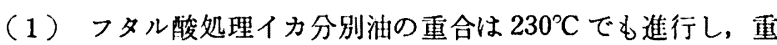
合油の性状の変化から重合機構は重合温度の影響をうけず, 主と して分子間重合であると認められ，(2）ヨウ素価の减少度合か ら各重合温度の速度定数を求め, 活性化熱として $18.3 \mathrm{kcal} / \mathrm{M} の$ 伯を得た。（3）マレイン酸処理油の $12.8 \mathrm{kcal} / \mathrm{M}$ より活性化熟 が高いのはマレイン酸基の二重結合の官能基によると思われ, （4）重合油およびアセトン不溶部は完全に硬化乾燥を行 万が, （5）アセトン可溶部は重合が進むにつれて晞燥速度が低下し, 遂には乾燥性を失5。(6) フタル酸処理イカ分別油の塗膜の黄 変は重合により改善できる。

（本報の一部は昭和 29 年 3 月, 日本油脂化学協会講演会講演） 終始御指尊を賜わった相談役竹井俊郎氏および原稿の御校閲を いただいた名大教授外山修之先生に深謝する。

\title{
（143） イ力分別油の重合之乾燥 性†
}

(昭 和 30 年 1 月 17 日受理)

\author{
丸茂秀雄・中島昭・富山新 -**
}

魚油の乾燥性が不良なのは比較的多量に含まれる飽和酸基のた めであると古くから信じられてきた。しかし，魚油から飽和酸基 を除去する方法として工業化されたものは極く僅かである。まず 加水分解して脂肪酸を分留し，不飽和酸部を再びグリセリンでエ ステル化する Armour \& Co. の方法が工業化され(1), 続いてフ ルフラールによる分別抽出法も工業化されたが2)，現在は操業は 魚油については行われていない上うである。液体プロパンによる ソレキソール法3)は魚油については米国ではまだ本格的な操業は 行われていないようであるが, 南アフリカでは Pilchard Oil に ついて業化が完成し, 現在ヨウ素価 200 以上の分別抽仙油を商 品名“Marinol”として市肘している4。

丸茂，富山は魯油から飽和酸基を除去する手段として低温エス

$\dagger$ 本報を「重油の乾燥性とその改善に関する研究（第 7 報）! とする。

* ライオン油脂株式会社研究部 : 東京都汪户川区.

1) D. V. Stingley, Ind. Eng. Chem. 32, 1217 (1940).

2) S. W. Gloyer, ibid. 40, 228 (1948).

3) H. J. Passino, ibid. 41, 280 (1949).

4) H. W. Chatfield, Paint Oil \& Colour J. 123, 27 (1953).
テル基交換5), 脱ロウ(゙)を所究し, 操作も簡等で収率もよい実施 条件を確定して工業化をすでに完成した。ひき続いてイカ油から 低温エステル基交換, 脱口ウの操作で得た飽和酸含量の低いイカ 分別油の乾燥性を検訪してきた。

まず第 1 報7)ではイカ分別油の乾燥試験を行い, $300^{\circ} \mathrm{C}$ 減圧の 重合結果から粘度変化よりの重合速度定数を求めた。重合油の乾 蜗試験結果から $300^{\wedge} \mathrm{C}$, 減压の重合条件では熱重合以外に熱によ る化学変化がおこり, 重合油の乾燥性がある程度まで改善される 旨を推論した。続いて (第 2 報8)，第 3 報9)）モノ，ジグリセリド が乾燥性に影響を与える重要な因子であり，モノ，ジグリセリド の遊離水酸基をマレイン酸, フタル酸でェステル化する二塩基性 酸処理によって乾燥性が改善されることを明らかにした。 次に，二塩基性酸処理を行ったイカ分別油の熱重合および重合

5）丸茂，䈍山，油脂化協 2，232 (1953).

6）丸茂，篦山，油脂化協 2，235 (1953)，3，6 (1954).

7）丸茂，富山，油脂化協 3，9 (1954).

8) 丸茂, 富山, 油脂化協 3, 67 (1954).

9) 丸茂, 䈏山, 油脂化協 3, 70 (1954). 